\title{
Methods and characteristics of commercial advertising in the socio-cultural context of the New Economic Policy (NEP)
}

\author{
Natalyja Shishova ${ }^{*}$ \\ ${ }^{1}$ Don State Technical University, 1. Gagarin sq., 344003, Rostov-on-Don, Russia
}

\begin{abstract}
The publication analyzes the advertising practice in Soviet Russia (the Union of Soviet Socialist Republics) in the 1920s - during the period of the new economic policy. The reasons for the advertising renaissance during the NEP period are indicated, the leading of which are the refusal of the Bolshevik leadership from the policy of "war communism" and the restoration of exchange relations. The author's opinion is justified, according to which commercial advertising during the NEP was a synthesis of pre-Soviet methods and Soviet innovations, and the latter modified not only the style of advertising activities but also its goals and objectives, giving them a politicized character. The article considers and characterizes both the socio-cultural specifics of the NEP and its impact on commercial advertising in the RSFSR (USSR). Which were expressed in the creation of innovative advertising texts and visual images, ideologization and a certain militarization of the advertising language, etc.
\end{abstract}

\section{Introduction}

The issues of the development of commercial advertising in Soviet Russia (the Union of Soviet Socialist Republics) during the NEP period are not among those covered in detail and in detail in the scientific literature. During the Soviet period, the issues of advertising activities were usually ignored since, in the conditions of a planned economy, advertising was not in demand. Only in the post-Soviet epoch, the attention to the history, theory, and practice of advertising today has significantly increased on the part of both domestic and foreign researchers [1-13]. Nevertheless, within the boundaries of the designated topic, there are many unfilled niches, such as the influence of pre-Soviet traditions and Soviet innovations on advertising activities, the construction of methods and characteristics of this activity under the influence of socio-cultural features of the NEP period, etc.

These issues require further study and give such a topic as Soviet advertising during the NEP period a pronounced scientific and theoretical relevance. In addition to the scientific and theoretical, the topic under consideration is also of practical importance since the results of the study of advertising techniques of the past can be used in the development of modern approaches and methods of advertising. In particular, the analysis of advertising

* Corresponding author: natali.shishova7@mail.ru 
activities within the boundaries of a particular historical era indicates the decisive impact on the practice of advertising of public attitudes, preferences, and mental images that are widespread in this era.

The degree of awareness and consideration of such socio-cultural characteristics of advertising producers largely determine the success or failure of the latter. Given that the views and mental attitudes that are widespread in society are extremely strong and are transmitted from generation to generation, the task of studying the influence of sociocultural specifics on advertising activities in the past is very important for modern advertisers. From the point of view of the analysis of the problem of determining advertising by the socio-cultural specifics of society at a particular stage of its development, the NEP period seems to be one of the most promising for researchers. In the $1920 \mathrm{~s}$, the RSFSR (USSR) had a unique situation of coexistence of both Soviet innovations and elements of the pre-Soviet system in almost all spheres of society. Therefore, within the framework of this publication, we have focused on the socio-cultural specifics of the NEP and its impact on advertising practices and their final product.

\section{Materials and methods}

The empirical basis of the presented publication is scientific publications on the development of advertising in Russia, periodicals of the 1920s, testimonies and memoirs of contemporaries. In scientific publications, among which it is necessary to highlight the work of Glinternik, there are examples of graphic advertising, including those dating back to the 1920s. Their analysis allows us to identify several significant characteristics of advertising activities in Soviet Russia (USSR) during the NEP period. In the periodicals of the 1920s, there are also many examples of graphic advertising and advertising texts, and a significant number of them did not attract the attention of researchers and were not understood in the scientific literature. The author used illustrated magazine "Krasnaya Niva", published during the NEP period, and the newspaper "Molot", published in Rostovon-Don. Important for our work are the testimonies of contemporaries about what advertising practices were used in the 1920s. Here we should note the memoirs of famous writers Paustovsky "The Book of Life" and Golitsyn "Notes of the Survivor", as well as Bulgakov's descriptions of Moscow in the early 1920s.

The leading methods in the process of our research were comparative-historical and historical-genetic. The first of them allows us to identify common and special in the preSoviet and early Soviet (NEP) methods of advertising, to establish the degree of correlation between traditions and innovations in advertising during the NEP period. The second provides tools for identifying the continuity of both public consciousness and advertising practices in the pre-Soviet era and during the NEP period.

\section{Results}

The transition to the NEP in the early 1920s meant the restoration of market relations, without which commercial advertising seemed irrelevant. All this in the shortest possible time stimulated advertising activities in Soviet Russia (the Soviet Union). At the same time, during the NEP period, neither commerce nor commercial advertising were exact casts of pre-revolutionary analogs but bore the imprint of the Soviet reality that was being born and strengthened.

First, in the sphere of industrial production and trade, the leading role belonged not to entrepreneurs, but the state. The transition to the NEP, proclaimed by the leaders of the Communist Party, in no way meant abandoning the course of building socialism. Forced to 
allow private property and individual entrepreneurship, the Bolsheviks were determined to limit their development in every possible way and, on the contrary, to strengthen socialist forms of ownership and promote the ideals and principles of socialism in society. Therefore, Soviet advertising in the 1920 s was not limited exclusively to the sphere of commerce. Its super-task was to strengthen the socialist sector of the economy and the Soviet state, to promote the ideas of the revolution to the masses, and, ultimately, to promote the victory of socialism in Russia and the Soviet Union. One of the Soviet authors wrote with good reason about the role of advertising in strengthening the Soviet power in the minds of the population: "Among the various issues that the scientific organization of labor deals with the issue of advertising should be given a prominent place... The results established by the works on the psychology of advertising will contribute to the practice of not only economic but also political life, giving the necessary weapons to the propaganda of the ideas of [socialism among the population of the USSR] " (Ryzer.Advertising / / Krasnaya Niva. 1925. No. 25. P. 584).

Within the framework of achieving this goal, advertising activities in the Soviet Union were designed in such a way as to infringe on the private sector and create a most-favorednation regime for state-owned or cooperative (i.e., socialist) enterprises. Active advertising was supposed to prove the advantages of state-owned enterprises over the participants, to convince the population of the high quality of their products, affordable and democratic prices. Outstanding masters born of the revolutionary era worked on the production of such advertising. A vivid example is the work of V. V. Mayakovsky and the artist A.M. Rodchenko. According to the memoirs of the latter, he and Mayakovsky sought to "everywhere" distribute qualitatively new advertising that corresponded to the spirit of the era. This advertising and creative duo, in which Mayakovsky played the role of the creator of advertising texts, and Rodchenko - visual images (posters, drawings in magazines and newspapers, etc.), collaborated with many Soviet enterprises and associations - Gosizdat, Rezinotrest, Moscow department store GUM. The services of the duo were used by such a commercial and industrial giant as the Moscow State Food Trust "Mosselprom". Rodchenko became the author of many advertising posters, and Mayakovsky created many catchy and memorable advertising texts, including the famous slogan "nowhere but in Mosselprom".

The innovations introduced into the life of Russia by the Soviet government had a decisive impact not only on the approaches to advertising but also on the style of advertising and its content. This was clearly shown in the advertising poster. At first, Soviet advertising was strongly influenced by previous experience. The advertising posters, chronologically related to the Soviet era, but made in the characteristic "modern" style, which appeared in Russia at the end of the 19th century, are indicative. Such is the advertisement of the magazine "Red Plowman" (author of Apsit, 1919), where we see a certain epic Mikula with a red flag with the inscription, "Proletarians of all countries, unite". This is the poster of the state labor savings banks, where a bearded peasant in wide boots, a Russian folk shirt with embroidery leans his hand on a poster explaining how savings banks are profitable, and at the bottom lies a broken pot with coins that have fallen out of it. To a certain extent, the pre-Soviet images in the advertising posters of the Soviet era were explained by nostalgia, as in modern post-socialist Russia [14].

However, the situation changed rapidly and already in the early first half of the 1920s. The Soviet advertising poster and, in general, visual advertising methods, went far away from the pre-revolutionary advertising graphics. There were many new creative techniques, among which stood out photomontage, which had a stunning effect on the audience. Among artistic movements and styles of posters widest popularity of constructivism, whose members were for the simplicity of the image and the brevity of graphical tools for democracy clarity understandable to the masses. A well-known representative of 
constructivism as a direction of advertising graphics in the USSR during the NEP period was deservedly Rodchenko, whose outstanding talent allowed him to create memorable posters. Rodchenko owns several outstanding and sometimes ambiguous visual images, such as "Kinoglaz", the man from the advertising of "best teats" for children from Rezinotrest (a strange creature with a red-green head), a bottle of beer "Trekhgornoye", smashing competitors such as moonshine, etc. One of Rodchenko's most famous works is an advertising poster of the publishing house Lengiz "Books on all branches of Knowledge", which depicts the" muse of the Russian avant-garde " Lilya Brik in the image of an agitator-a girl in a red kerchief (a characteristic headdress of the Komsomol and communist women of the 1920s). Such images were extremely uncharacteristic of preSoviet advertising and represented an undoubted innovation in Russia in the first postOctober decade. Here it is impossible not to agree with those researchers who point out the trends of changing images of the human body in advertising within the chronological boundaries of certain epochs [15].

Under the influence of socio-cultural processes in the RSFSR (USSR), the style of advertising during the NEP significantly changed. In comparison with the pre-Soviet era, the advertising slogan of the 1920s looks chased, sharp, assertive, more rigid, and even rude. It is significant that in the advertising of the specified period, the expression "demand" is often found, and not " ask»: "Demand confectionery products of Mosselprom state factories", " demand in all pharmacies and stores [Izhevsk water, an indispensable table drink]" (Krasnaya Niva. 1925. No. 27. p. 639), etc. The advertising reflected the general coarsening of morals, so characteristic of a country that has experienced revolutionary upheavals and a fierce civil conflict.

The readiness of the Soviet society for a new war, to repel a possible foreign intervention, also had a certain impact on the language of advertisements. In this respect, typical toothpaste ad "Kaladont», it sounded like the call " Be vigilant! »: « Guard the front vigilantly - // - oral cavity and teeth // buy "Kaladont»// with the brand " AKO " tubes»" (Krasnaya Niva. 1927. No. 35. p. 20).

In advertising practice, there was also an appeal to the Russian style, popular in the late 19th century. Traditional painting techniques are presented in the advertising of sweets from the above-mentioned Mosselprom.

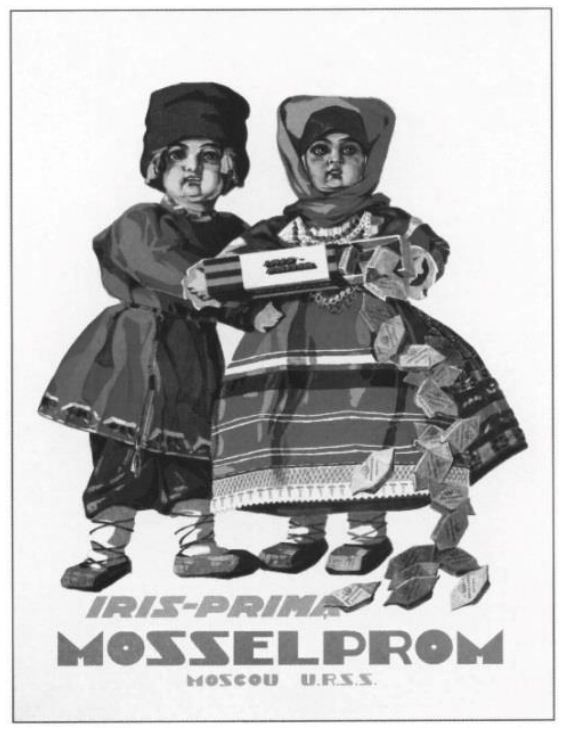

Fig.1. Zelenskii A. 1930. 
Of course, advertising constantly reminded consumers that they lived in the Soviet state and were imbued with the spirit of denial of pre-revolutionary reality. This message is contained in the advertising poster of cigarettes "Soviet", which depicts a worker with a box of cigarettes, disrespectfully holding the collar of a puny old man in the ornate uniform of a civil official of imperial Russia. The inscription on the poster reads: "We don't smoke senatorial [cigarettes] - give us Soviet ones!"

Although during the NEP period, the priority belonged to advertisements of state-owned and cooperative enterprises (which was inevitable in the state economy typical of the Soviet era), advertising of private producers and entrepreneurs - "supporters of NEP advertising" also occupied a prominent position at this time. The forms and scale of private advertising varied and ultimately depended on the financial capabilities of the advertiser: richer entrepreneurs could afford to order bright and catchy advertising and distribute it widely, unlike less affluent customers. Often, private advertising of the 1920 s was primitive-archaic and limited only to signs. Bulgakov recorded in the autumn of 1922 how " on the bare walls [of houses in Moscow], a wave of colored signs climbed, every day new, every day larger and larger." In some places, the signs were made in haste, sometimes simply written on canvas, but quite quickly permanent ones appeared next to them, with the text made in bright large letters and considering the new spelling, without a solid sign at the end of the words (Mikhail Bulgakov. Trade Renaissance. M., 1988. p. 379). According to Golitsyn's memoirs, in Moscow at that time there were many pubs (their signs were marked with horizontal green and yellow stripes), "there were Jewish canteens with signs in two languages" (Sergey Golitsyn. Notes of the survivor. M., 1990. p. 127).

The next stage of private advertising was ads in newspapers as the most common mass media. The editorial office of the leading Soviet newspaper Izvestia in November 1922 opened the reception of advertisements not only from state institutions and cooperatives but also from private individuals. Advertising was even placed in the print edition of the Communist Party - the newspaper "Pravda".

In some cases, private advertising impressed with its originality. Thus, contemporaries testified that during the NEP period in Moscow, the "king of charcoal" Yakov Ratser was widely known. He paid a lot of attention to advertising his products among the population of the capital. One of the methods of its advertising was to place an inscription on the carts with its products, indicating that the charcoal was sold by Yakov Ratser, and by no one else. According to Paustovsky's recollection, his advertising stood out due to its extraordinary style and sounded like this: "There were cases that Yakov Ratser's coal was not heavy, but there were no cases that Yakov Ratser's coal was raw." In addition, on the packaging of samovar coal, Ratzer printed a poetic advertisement:

"Thus, saith Zarathustra:

"Who advertises smartly,

But it does not captivate with the product,

He advertises for nothing."

Do you need coal or firewood?

Ratser firm hardly

It will be forgotten by Moscow, -

Glory is not won for nothing!".

It may seem strange that Ratzer, as an authoritative advertising theorist, referred to Zarathustra. What does the author of "Avesta" have to do with advertising? But the fact is that in this case, we are not looking at the founder of Zoroastrianism, but the hero of $\mathrm{F}$. Nietzsche's book "Thus Spake Zarathustra" written in 1883 (under the impression of this work, R. Strauss created a symphonic poem of the same name). The book was translated into Russian and received quite a wide popularity among the reading public; its name became for some time a kind of winged expression, the meaning of which, probably, could 
be expressed by the words " truly so!". It was this Zarathustra, a literary character created by Nietzsche, that Jacob Ratzer took as a witness to the high quality of his goods. Paustovsky also wrote about another well-known entrepreneur in Moscow named Fynk, who was engaged in the production of shoe polish. Fynk used to advertise his product cut out of tin men. These figurines were hung on poles and provided with inscriptions-calls to clean shoes exclusively with Funk paste (Konstantin Paustovsky. A book about life. In two volumes. Vol. II. M., 1966. p. 541-542). It is difficult to say how effective such annoying advertising was. Experts reasonably point to the" wear and tear " of advertising due to its frequency, which is why the once new and attention-grabbing advertising becomes familiar and loses its quality to attract interest in the product. There is no doubt, however, that the " supporters of NEP advertising " of the 1920s understood the huge role of advertising in the successful sale of their products.

We should add that when reading ads in Soviet newspapers (such ads were placed on the last page), a significant proportion of ads by doctors, most of whom were specialists in venereology, attracts attention. In particular, the abundance of such advertising is striking when reading the newspaper "Molot", published in Rostov-on-Don. In one of the September issues of the "Molot" for 1925, doctors G. S. Balabanov, S. M. Brailovsky, N. M. Bryantsev, L. Konikov, A. P. Lavrov, who were engaged in the treatment of syphilis and other venereal diseases, skin diseases, "sexual impotence", offered their services: each of them gave their own advertising. Similar services, as well as "massage for sexual impotence", were offered by S. V. Trumpeldor, who proudly indicated in his advertising that he worked "abroad in the clinic of Prof. I. V. Zabludovsky" (Molot. September 23). In one of the Octobers (1925) issues of "Molot", in addition to the already familiar L. Konikov and S. M. Brailovsky, venereologists R. L. Gorelov, A. Lichtenstein, B. N. Toniyan, Chubukhchiev, V. P. Shlyakhetsky, P. I. Schnee, "Doctor Isidor Matveyevich Shpuntov" (Molot, 1925. October 22). Active advertising of venereologists reflected the high demand for their services. In a country that has been experiencing violent upheavals for several years, venereal diseases have become very widespread both in cities and in rural areas.

\section{Discussion}

As we can see, the NEP period was a time of not only the revival of commercial advertising in its pre-Soviet versions but also the development of Soviet advertising, filled with new ideas and images, characterized by a new style. The economy of the NEP period, in which trade and market relations played an important role, led to an advertising renaissance. However, it is safe to say that the same socio-economic processes that stimulated the development of advertising during the NEP period caused the short-lived and collapse of the advertising renaissance of the 1920s.

Here it is important to emphasize that, although the NEP was conditioned by objective socio-economic processes, it did not cause enthusiasm among the Bolshevik elite, since it created conditions for strengthening the positions of the city ("supporters of NEP advertising ") and the rural ("kulaks") bourgeoisie. The leaders of the Communist Party noted with alarm the rampant market element and spoke of the need to strengthen planning as one of the leading principles of the Soviet economy. A characteristic expression is contained in the resolution of the April (1926) plenum of the Communist Party: "At present... the strengthening of the planned beginning and the introduction of a regime of planned discipline in the activities of all State bodies are of particular importance."

Therefore, the new economic policy was doomed to liquidation, which happened in the late 1920s. In November 1929, I. V. Stalin published his famous article "The Year of the Great Turning Point". In essence, the article proclaimed the scrapping of the NEP and the 
transition to the forced construction of socialism in the form that it was understood by the Bolshevik ideologists.

Advertising was the voice of the market and, as one of the phenomena accompanying the NEP, also caused the rejection of many party and Soviet officials. It is symptomatic that the party resolution of April 16, 1926, condemned the dominance of commercial advertising in the party press. Obviously, the leaders of the Communist Party considered this problem quite acute since they reacted to it with the adoption of a special resolution. The" Great Turning Point", proclaimed in November 1929, dealt a fatal blow to commercial advertising, which lost its meaning in the absence of a market.

\section{Conclusions}

Thus, commercial advertising, which experienced a brief renaissance in the 1920s, differed from pre-Soviet advertising practices in several features that were generated by the sociocultural specifics of the NEP. In contrast to the pre-revolutionary era, during the NEP period, advertising did not come to the fore for private producers and entrepreneurs, but for state and cooperative enterprises, institutions, and associations. The turbulent time of revolutionary transformations had a direct impact on the directions and methods of advertising, on its style, language, appearance, and the list of leading signs and symbols. To a certain extent, the language and images of advertisements and posters have become more rigid and brutal; we can note the trend of a certain militarization of advertising, which was a reaction to the position of the USSR as a state that was in an unfriendly capitalist environment. The advertisements pointed to the ulcers of Soviet reality that had persisted since pre-revolutionary times to the wide scale of venereal diseases.

In general, the advertising of the 1920s reflected the mood characteristic of a significant part of Soviet society to continue the revolutionary transformation of reality, to build socialism, and to prepare to repel foreign intervention, if such a thing happens. At the same time, the language of advertisements also testified to the existence during the NEP period of a certain nostalgia for pre-revolutionary Russia, about the ideological split of society, which steadily deepened with the development of commodity-market relations and the associated strengthening of the positions of the urban and rural bourgeoisie. All this increased the negative attitude of the party-Soviet leadership to the NEP and became one of the reasons for the breakdown of the new economic policy implemented in the 1920s, along with which commercial advertising also went into oblivion.

\section{References}

1. E. Oglezneva, T. Petrova, J. Ying, Procedia - Social and Behavioral Sciences, 236, 194 - 200 (2016), doi.org/10.1016/j.sbspro.2016.12.064

2. T. Kossova, E. Kossova, M. Sheluntcova, Evaluation and Program Planning, 69, 43 52 (2018), doi.org/10.1016/j.evalprogplan.2018.04.006

3. A. Merkin, A. Nikolaev, M. Glover, Global Epidemiology, 3, (2021), doi.org/10.1016/j.gloepi.2020.100043

4. E. B. Restrepo, Pre-History of Advertising Administration (North University, 2016)

5. L. Daymette, D. Montenegro, The history of advertising (Universidad de Matanzas "Camilo Cienfuegos", 2017)

6. C. Meyers, American Journalism 8, 47 - 56 (2020)

7. K. Gori, A Brief History of Advertising. Marketing Communications (Goodfellow, 2016) 
8. F. Beard, A history of advertising and sales promotion. The Routledge Companion to Marketing History (2016)

9. N. Holm, The history of advertising: Contexts, transformations and continuity (2017), doi: 10.1057/978-1-137-47175-8_2.

10. E. Applegat, The Rise of Advertising in the United States: A History of Innovation to 1960 (Scare-crow, Plymouth, UK, 2012)

11. G. Bakker, Soft Power: The Media Industries in Britain since 1870 (London School of Economics and Political Science, Department of Economic History, Working Papers, n. 200, 2014)

12. W. Leiss, et al., Social Communication in Advertising, consumption in the Mediated Marketplace (Routledge, New York-London, 2015)

13. N. Shutova, V. Moshchevitina, Russian Journal of Multilingualism and Education (2020), doi:10.35634/2500-0748-2020-12-163-172.

14. S. L. Holak, A. V. Matveev, W. J. Havlena, Journal of Business Research, 60, 649 655 (2007), doi.org/10.1016/j.jbusres.2006.06.016

15. L. Camerino, O. Camerino, M. Castañer, Physiology \& Behavior, 220, (2020), doi.org/10.1016/j.physbeh.2020.112869

16. A. Kronrod, J. Huber, International Journal of Research in Marketing, 36, 306 - 324 (2019), doi.org/10.1016/j.ijresmar.2018.11.008

17. C. S. Craig, Encyclopedia International Advertising International Encyclopedia of the Social \& Behavioral Sciences, 2nd edn. (2015) 